\title{
GENOTOXICITY OF THE CYCLO-OXYGENASE-INHIBITOR SULINDAC SULFIDE IN THE FILAMENTOUS FUNGUS Aspergillus nidulans
}

\author{
Claudinéia Conationi da Silva Franco; Claudia Tiemi Miyamoto; Juliane Rocha de Sant'Anna; \\ Marialba Avezum Alves de Castro-Prado*
}

Universidade Estadual de Maringá, Departamento de Biologia Celular e Genética, Maringá, PR, Brasil

Submitted: September 27, 2006; Approved: April 09, 2007.

\begin{abstract}
Sulindac sulfide is a non-steroidal anti-inflammatory drug (NSAID) with chemopreventive effect on human cancer cells. Due to the involvement of the somatic recombination in the carcinogenic process, sulindac sulfide's recombinogenic potential was evaluated by the Homozygotization Index (HI) in the filamentous fungus Aspergillus nidulans. The drug's recombinogenic potential was evaluated by its capacity to induce homozygosis of recessive genes from heterozygous diploid cells. Sulindac sulfide at 175 and $350 \mu \mathrm{M}$ concentrations induced mitotic recombination in A. nidulans diploid cells, with $\mathrm{HI}$ values for genetic markers higher than 2.0, and significantly different from control HI values. The recombinogenic effect of NSAID was related to the induction of DNA strand breaks and cell cycle alterations. Sulindac sulfide's carcinogenic potential was also discussed.
\end{abstract}

Key words: antineoplastic agents, mitotic crossing-over, secondary malignances.

\section{INTRODUCTION}

Non-steroidal anti-inflammatory drugs (NSAIDs) are primarily analgesic, anti-inflammatory and antipyretic compounds which inhibit the cyclo-oxygenase-mediated production of prostaglandins $(1,3)$. Two COX isoenzymes, COX1 and COX-2, exist in human cells. The former (COX-1) is constitutively expressed, whereas the latter, inducible isoenzyme COX-2, is expressed only in response to tumor promoters, endotoxin, cytokines and hormones $(10,27)$. The main product of COX-2, namely prostaglandin $\mathrm{E}_{2}\left(\mathrm{PGE}_{2}\right)$, is found at high levels in tumor cells. In clinical studies, $\mathrm{PGE}_{2}$ have been associated with high metastatic potential of neoplastic cells $(25,26)$.

Several studies have reported an inverse relationship between cancer incidence and regular use of NSAID, including aspirin $(12,15)$. The dietary administration of NSAIDs, such as ibuprofen and celecoxib, significantly reduced the incidence, multiplicity and volume of tumors in female Spragne-Dawley rats with 7,12-dimethylbenzathracene-induced mammary carcinomas $(9,24)$. Celecoxib also induced apoptosis in human prostate cancer cell (11).
Sulindac is a non-steroidal anti-inflammatory drug with prophylactic effects in the prevention of colon cancer. Sulindac and its metabolites, such as sulindac sulfide, inhibited the proliferation in cultured colon cancer cells and induced DNA strand breaks and cell death by apoptosis $(22,23)$. Patients with familial adenomatous polyposis showed reduction of both the number and size of colorectal adenomas after the administration of sulindac (21).

In a variety of human tumor cells, including human lung squamous cells and human leukemia cell lines, sulindac and other NSAIDs enhance the cytotoxicity of certain anticancer drugs, such as doxorubicin, daunorubicin and epirubicin. Results suggest that active NSAIDs inhibit MRP-mediated drug efflux which confers multidrug resistance (MDR) (5,6). Classical MDR is characterized by cross-resistance to a range of chemically unrelated drugs, whereas MRP (MDR-associated protein) is a transmembrane transporter (18).

Sulindac sulfide's chemopreventive effect has been recently associated with alterations in the gene expression in gastric and ovarian cancer cells. Sulindac sulfide has been characterized as a NAG-1 gene inducer in ovarian cancer cells. Since human

*Corresponding Author. Mailing address: Universidade Estadual de Maringá, Departamento de Biologia Celular e Genética, Avenida Colombo 5790, Maringá PR Brazil 87020-900. Tel.: (44) 3261-4679. E-mail: maacprado@uem.br 
NAG-1 is linked to apoptosis, the reduced expression of NAG1 gene may enhance tumorigenesis $(12,16,17)$.

Since somatic recombination is mechanisma leading to carcinogenesis $(7,8)$, current in vivo study shall evaluate the genotoxicity of sulindac sulfide in heterozygous cells of Aspergillus nidulans.

\section{MATERIAL AND METHODS}

Strains and culture media. Diploid strain was formed with UT448 and A757 haploid strains (Table 1). Minimal Medium (MM) comprised Czapek-Dox with $1 \%$ (w/v) glucose, whereas Complete Medium (CM) consisted of peptone $(2,000$ $\mathrm{mg} / \mathrm{L})$, yeast extract $(2,000 \mathrm{mg} / \mathrm{L})$, hydroliysed casein $(1,000$ $\mathrm{mg} / \mathrm{L})$, glucose $(10,000 \mathrm{mg} / \mathrm{L})$, biotin $(2 \mathrm{mg} / \mathrm{L})$, pyridoxine $(50$ $\mathrm{mg} / \mathrm{L}), p$-aminobenzoic acid $(50 \mathrm{mg} / \mathrm{L})$, folic acid $(50 \mathrm{mg} / \mathrm{L})$, nicotinic acid (100 mg/L), pantothenic acid $(200 \mathrm{mg} / \mathrm{L})$, choline chloride (200 mg/L), riboflavin (100 mg/L), inositol (400 mg/L) and thiamine (50 mg/L) added to MM. Selective medium (SM) comprised MM plus riboflavin, $p$-aminobenzoic acid, biotin, methionine and pyridoxine, while solid medium contained $1.5 \%$ agar. Incubation for strain growth occurred at $37^{\circ} \mathrm{C}$.

Sulindac sulfide treatment. Drug concentration that induced the arrest of the human colon adenocarcinoma cell in G1/S phase $(175 \mu \mathrm{M})(23)$ and a higher concentration $(350 \mu \mathrm{M})$ were used in present study. They were the final ones in MM. Sulindac sulfide was dissolved in $10 \mu \mathrm{L}$ DMSO and added to molten MM. Solvent was per se neither visibly toxic (Fig. 1) nor recombinogenic for diploid strain (results not shown).

Evaluation of drug toxicity. Conidia of diploid strain A757// UT448 were inoculated at the center of plates with MM (control) and MM + sulindac sulfide (treatment). Ten plates were inoculated for each dose and for controls and incubated at $37^{\circ} \mathrm{C}$. Measurement of colonies' diameter occurred after 48 to 144 hours incubation. Values in the presence and in the absence of the drug were compared by Student's $t$ test.

Table 1. Genotype and origin of A. nidulans strains.

\begin{tabular}{|c|c|c|}
\hline Strains & Genotype & Origin \\
\hline A757 & $\begin{array}{l}\text { yA2 (I), methA17(II), } \\
\text { pyroA4 (IV) }\end{array}$ & FGSC* \\
\hline UT448 & $\begin{array}{l}\text { riboAl (I), pabaA124(I), } \\
\text { biAl(I), AcrAl (II), wA2(II) }\end{array}$ & Utrecht \\
\hline
\end{tabular}

Requirements for: riboflavin $=$ ribo $\mathrm{A} 1, \mathrm{p}$-aminobenzoic acid $=$ pabaA124, biotin $=$ bioA 1 , methionine $=$ meth $\mathrm{A} 17$, pyridoxine $=$ pyroA4. Conidia color: white $=w A 2$; yellow $=y A 2$. AcrA1, resistance to acriflavine; $*$ FGSC $=$ Fungal Genetic Stock Center, University of Kansas Medical Center, Kansas, USA.

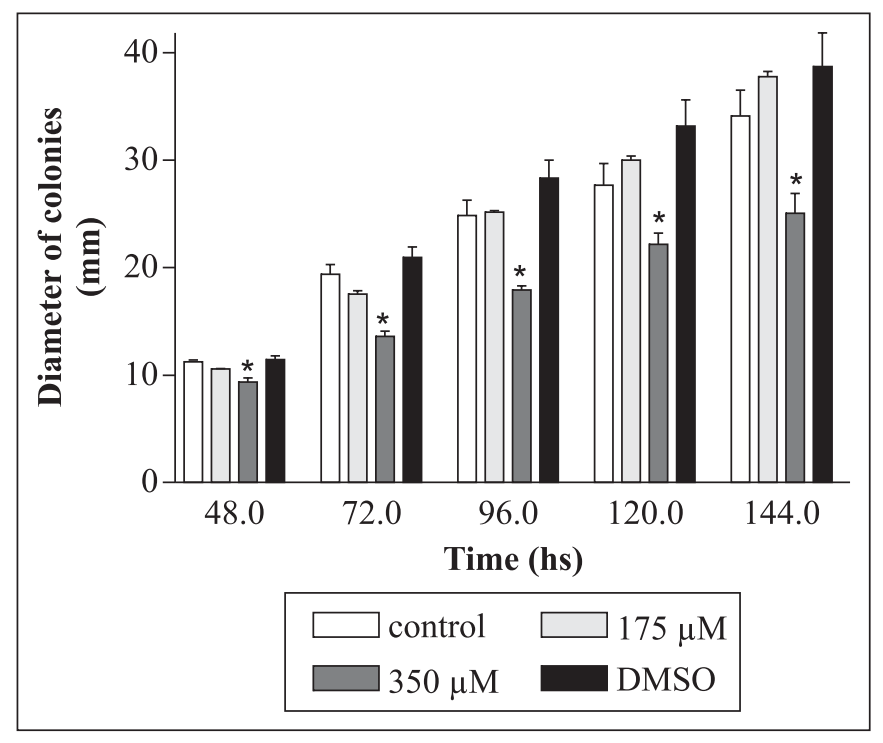

Figure 1. Growth of $A$. nidulans diploid strain A757//UT448 on plates containing Minimal Medium (control) and Minimal Medium plus sulindac sulfide $(175 \mu \mathrm{M}$ and $350 \mu \mathrm{M})$. (*) Strain growth significantly different from the control $(\mathrm{p}<0.05)$.

Calculating Homozygotization Index. Conidia of diploid strain A757//UT448 were individually inoculated in plates with $\mathrm{MM}+$ sulindac sulfide at 175 and $350 \mu \mathrm{M}$ concentrations. Plates were incubated for 5 days at $37^{\circ} \mathrm{C}$. Treatment produced visible mitotic sectors (D1-D6), identified by their morphology which differed from the original diploid (Fig. 2A-B). Diploid sectors were purified in MM and then transferred individually to plates with CM. They were then processed by spontaneous haploidization. After haploidization, the haploid mitotic segregants, obtained from diploids D1-D6, were purified in CM and their mitotic stability evaluated. Only mitotic stable segregants at the final stage were selected for the recombinogenesis test. Conidia of each haploid segregant were individually transferred to 25 positions in CM plates. After 48 hours incubation colonies were transferred to proper selective media to determine their phenotypes. Mitotic crossing-over causes homozygotization of heterozygous-conditioned genes. If sulindac sulfide induces mitotic crossing-over in diploid strain A757//UT448, only heterozygote (+/- or -/+) or homozygote (+/ $+)$ diploids will develop in MM. In this case, nutritional markers will segregate among the haploids at the proportion of 4+:2On the other hand, if NSAID does not induce crossing-over, proportion will amount to 4+:4-. This happens because the initial selection process limits the growth of diploids -/-. Homozygotization Indexes (HI) (the ratio between prototrophic segregants and auxotrophic segregants), equal to or higher than 2.0, indicate the sulindac sulfide's recombinogenic effect (13). Results were compared by Yates correct Chi-square test. 
Table 2. Homozygotization Index (HI) values for markers from UT448 // A757 diploid strain after treatment with $175 \mu$ M (D1-D3) and $350 \mu \mathrm{M}$ (D4 -D6) of sulindac sulfide

\begin{tabular}{|c|c|c|c|c|c|c|c|c|c|c|c|c|c|c|}
\hline \multirow{2}{*}{ Markers $^{\mathrm{a}}$} & \multicolumn{2}{|c|}{ Control $^{\mathrm{b}}$} & \multicolumn{2}{|c|}{ D1 } & \multicolumn{2}{|c|}{ D2 } & \multicolumn{2}{|c|}{ D3 } & \multicolumn{2}{|c|}{ D4 } & \multicolumn{2}{|c|}{ D5 } & \multicolumn{2}{|c|}{ D6 } \\
\hline & NS & HI & NS & HI & NS & HI & NS & HI & NS & HI & NS & HI & NS & HI \\
\hline ribo+ & 33 & 1.2 & 50 & 1.7 & 37 & 1.2 & 41 & 1.8 & 30 & 0.8 & 50 & 7.1* & 30 & 1.0 \\
\hline ribo & 27 & & 29 & & 30 & & 23 & & 36 & & 07 & & 29 & \\
\hline paba+ & 34 & 1.3 & 50 & 1.7 & 36 & 1.2 & 41 & 1.8 & 66 & nd & 50 & $7.1 *$ & 32 & 1.2 \\
\hline paba & 26 & & 29 & & 31 & & 23 & & 0 & & 07 & & 27 & \\
\hline$b i+$ & 33 & 1.2 & 54 & $2.2 *$ & 44 & 1.9 & 50 & $3.6^{*}$ & 57 & $6.3 *$ & 50 & $7.1 *$ & 40 & 2.1 \\
\hline$b i$ & 27 & & 25 & & 23 & & 14 & & 09 & & 07 & & 19 & \\
\hline meth+ & 33 & 1.2 & 71 & $8.9 *$ & 61 & nd & 58 & nd & 66 & nd & 56 & nd & 51 & $6.4^{*}$ \\
\hline meth & 37 & & 08 & & 06 & & 06 & & 0 & & 01 & & 08 & \\
\hline pyro+ & 31 & 1.1 & 49 & 1.6 & 39 & 1.4 & 41 & 1.8 & 38 & 1.35 & 32 & 1.3 & 42 & $2.5^{*}$ \\
\hline pyro & 29 & & 30 & & 28 & & 23 & & 28 & & 25 & & 17 & \\
\hline
\end{tabular}

${ }^{\mathrm{a}}$ ribo = riboflavin; $p a b a=p$-aminobenzoic acid; $b i=$ biotin; meth $=$ methionine and pyro $=$ pyridoxine. ${ }^{\mathrm{b}}$ Not treated with sulindac sulfide. *significantly different from control $(\mathrm{p}<0.05)$. nd= not determined $($ see text). NS = number of segregants.

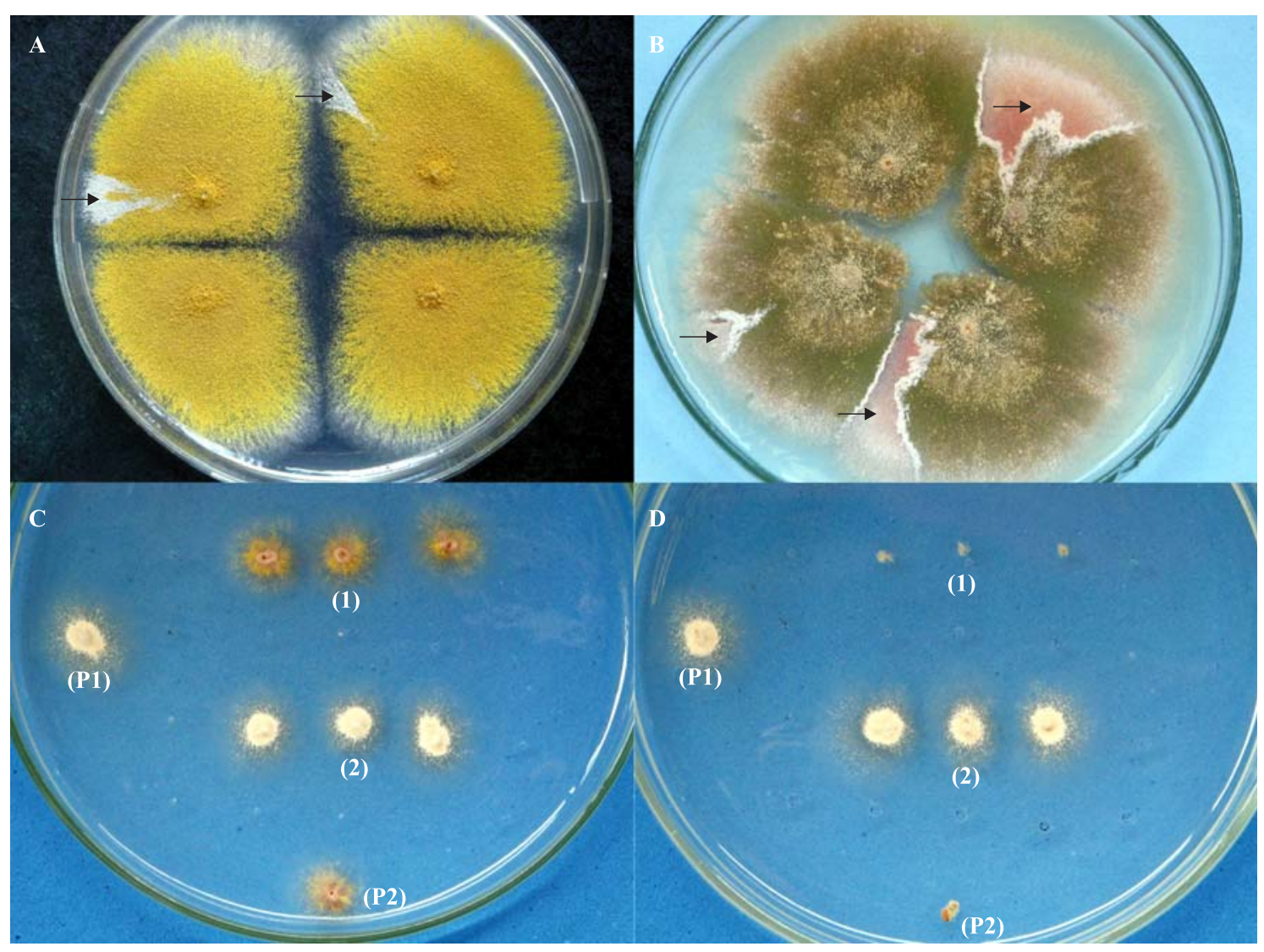

Figure 2. A-B, diploids D4 and D5, respectively, obtained after sulindac sulfide treatment of the original diploid A757//UT448 strain. Arrows indicate the mitotic segregants selected for the recombinogenesis tests. Mitotic segregants $w+$ meth (1) and $w$ meth + (2) from D2 and D3 diploids growing in the presence (C) and in the absence of methionine (D); P1 and P2 are the paternal UT448 and A757 stains, respectively. 


\section{RESULTS AND DISCUSSION}

Current researchers first examined the manner sulindac sulfide affected the mycelial growth of the fungal strain. When compared to control (untreated conidia), fungal growth was significantly inhibited after cell exposition to $350 \mu \mathrm{M}$ sulindac sulfide (Fig. 1). Since sulindac sulfide caused strong inhibition of $\mathrm{G} 1$ to $\mathrm{S}$ phase of the cell cycle on cultured human cancer cells (14), the cytotoxic effect of NSAID in A. nidulans diploid cells might be explained by cell cycle delay or by cell death mechanism.

Sulindac sulfide's genotoxicity was evaluated in current study by its capacity to induce homozygosis during the mitotic propagation of the heterozygous diploid A757//UT448 strain. Results show (Table 2) that cytotoxic $(350 \mu \mathrm{M})$ and noncytotoxic $(175 \mu \mathrm{M})$ concentrations of the drug significantly increased HI values of the nutritional markers when compared to those of control.

Diploids D1 and D3, derived from A757//UT448 strain after treatment with $175 \mu \mathrm{M}$ sulindac sulfide, showed homozygotization indexes over 2.0 for $b i$ and $m e t h$ genes. Results indicate the occurrence of mitotic crossing-over on chromosomes I and II from the original diploid strain. HI values for meth gene from mitotic segregants derived from D2 and D3 strains could not be determined because the meth segregants obtained in the analyses were not phenotypically recombinant, but parental (w+, meth) (Fig. 2C-D). Contrastingly, all meth segregants obtained after haploidization of D1 strain were recombinants $w$, meth (Tables 1 and 2).

Diploid strains, obtained with $350 \mu \mathrm{M}$ sulindac sulfide (D4 to D6), showed ribo, paba, bi, meth and pyro genes HI values higher than 2.0 and significantly different from respective control HI values. The absence or the reduced number of meth segregants derived from D4 and D5 strains, respectively, may be justified by a greater number of white $(w)$ segregants isolated after haploidization. In the paternal UT448 strain the $w$ gene is closely linked to the meth + gene and consequently most of the $w$ segregants have the $w$ meth + phenotype. Similar to the D2 and D3 analyses, the meth segregant recovered after D5 haploidization was not phenotypically recombinant (Table 2 ).

Although the treatment of original A757//UT448 diploid with sulindac sulfide in MM does not allow the isolation of auxotrophic diploids (-/-), recessive homozygous diploids for conidia color $y$ marker may be obtained. The $175 \mu \mathrm{M}$ sulindac sulfide treatment of A757//UT448 diploid strain only allowed the isolation of prototrophic diploids with green conidia $(y+/ /$ $y$ ). On the other hand, homozygous $y / / y$ diploid strains were obtained (D4 and D6) with sulindac sulfide at $350 \mu \mathrm{M}$ concentration. The segregation of markers from chromosome I (ribo, paba and bi) among the mitotic segregants of D6 strain indicates the heterozygous condition for genes: On the other hand, the absence of paba segregation in D4 analysis suggests a homozygous condition for this marker in D4 diploid strain (Table 2).

As a whole, results show that sulindac sulfide is an effective somatic crossing-over inducer in diploid cells of $A$. nidulans. Sulindac sulfide's recombinogenic potential may indicate a direct effect of the drug on DNA, inducing the occurrence of DNA breaks and cell cycle alterations.

Cancer is a progressive process which results from environmental and endogenous agents' toxic effects. The disease develops from a single oncogenic mutation-bearer cell (either a proto-oncogene or a tumor suppressor gene) whose primary mutagenic event is called initiation. Since clonal expansion of an initiated cell is necessary for the fixation of the first mutation and tumor promotion, the probability is high for additional genetic alterations in decisive genes required for the tumor progression (20).

Although a normal cell may be a mutation bearer in a tumor suppressor gene $(m)$ owing to the presence of the normal allele $(m+)$, the loss of the heterozygous condition, caused by mitotic recombination, may be the factor which advances neoplasm (19). Actually, the loss of heterozygosity in human retinoblastoma is the most common mechanism which triggers the transformation process of a normal cell and makes it a neoplastic one $(4,8)$. As a consequence of mitotic crossing-over, the mitotic products are rendered homozygous from all heterozygous loci distal to the point of exchange, if a recombinant and a parental chromatid segregate towards the same mitotic pole (2). Mitotic recombination, in fact, represents an important function in expressing deleterious or oncogenic mutations in heterozygous initiated cell.

Results in current study show that sulindac sulfide induces homozygosis of genes previously masked by the dominant allele. Consequently, the above anti-inflammatory drug may be characterized as a tumor promoter agent that potentially induces secondary malignancies by mitotic crossing-over.

\section{RESUMO}

\section{Genotoxicidade de sulfeto de sulindaco em Aspergillus nidulans}

Sulfeto de sulindaco é um antiinflamatório não-esteroidal com efeitos quimiopreventivos em cânceres humanos. O presente estudo teve como objetivo avaliar o potencial recombinagênico do sulfeto de sulindaco em células diplóides de Aspergillus nidulans. O efeito recombinagênico da droga foi demonstrado através da homozigotização de genes recessivos, previamente presentes em heterozigose. Os valores de HI (Índice de Homozigotização) para diferentes marcadores genéticos apresentaram-se maiores do que 2,0 e significativamente diferentes dos valores obtidos em sulfeto de sulindaco ausência da droga (controle). O potencial 
recombinagênico do sulfeto de sulindaco foi associado à indução de quebras na molécula do DNA e a alterações no ciclo celular. O potencial carcinogênico do sulfeto de sulindaco foi discutido no presente trabalho.

Palavras-chave: agentes antineoplásicos, crossing-over mitótico, malignidade secundária, recombinação somática

\section{REFERENCES}

1. Baron, J.A. (2003). Epidemiology of non-steroidal antiinflammatory drugs and cancer. Prog. Exp. Tumor Res., 37: 1-24.

2. Beumer, K.J.; Pimpinelli, S.; Golic, K.G. (1998). Induced chromosomal exchange directs the segregation of recombinant chromatids in mitosis of Drosophila. Genetics, 150(1): 173-188.

3. Brooks, P.M.; Day, R.O. (1991). Nonsteroidal antiinflammatory drugs - differences and similarities. N. Engl. J. Med., 324(24): 1716-1725.

4. Cavenee, W.K.; Scrable, H.J.; James, C.D. (1991). Molecular genetics of human cancer predisposition and progression. Mutat Res., 247(2): 199-202.

5. Chiuchetta, S.J.R.; Castro-Prado, M.A.A. (2002). Doxorubicin and etoposide induce somatic recombination in diploid cells of Aspergillus nidulans. Braz. J. Microbiol., 33(3): 255-259.

6. Duffy, C.P.; Elliott, C.J.; O'Connor, R.A.; Heenan, M.M.; Coyle, S.; Cleary, I.M.; Kavanagh, K.; Verhaegen, S.; O'Loughlin, C.M.; NicAmhlaoibh, R.; Clynes, M. (1998). Enhancement of chemotherapeutic drug toxicity to human tumour cells in vivo by a subset of non-steroidal anti-inflammatory drugs (NSAIDS). Eur. J. Cancer, 34(8): 1250-1259.

7. Froelich, J.J.; Schneller, F.R.; Zahn, R.K. (1999). The influence of radiation and chemotherapy-related DNA strand breaks on carcinogenesis: an evaluation. Clin. Chem. Lab. Med., 37(4): 403408.

8. Hagstrom, S.A.; Dryja, T.P. (1999). Mitotic recombination map of 13cen-13q14 derived from an investigation of loss of heterozygosity in retinoblastomas. Proc. Natl. Acad. USA, 96(6): 2952-2957.

9. Harris, R.E.; Alshafie, G.A.; Abou-Issa, H.; Seibert, K. (2000). Chemoprevention of breast cancer in rats by celecoxib, cyclooxygenase-2 inhibitor. Cancer Res., 60(8): 2101-2103.

10. Herschman, H.R. (1996). Prostaglandin synthase 2. Biochim. Biophys. Acta, 1299(1): 125-140.

11. Hsu, A.L.; Ching, T.T.; Wang, D.S.; Song, X.Q.; Rangnekar, V.M.; Chen, C.S. (2000). The cyclooxygenase-2 inhibitor celecoxib induces apoptosis by blocking Akt activation in human prostate cancer independently of Bcl-2. J. Biol. Chem., 275(15): 11397-11403.

12. Jang, T.J.; Jung, K.H.; Choi, E.A. (2006). Id-1 gene downregulation by sulindac sulfide and its upregulation during tumor development in gastric cancer. Int. J. Cancer, 118(6): 1356-1363.

13. Kaneshima, E.N.; Castro-Prado, M.A.A. (2005). Benznidazoleinduced genotoxicity in diploid cells of Aspergillus nidulans. Mem. Inst. Oswaldo Cruz, 100(3): 325-329.
14. Karl, T.; Seibert, N.; Stohr, M.; Osswald, H.; Rosl, F.; Finzer, P. (2007). Sulindac induces specific degradation of the HPV oncoprotein E7 and causes growth arrest and apoptosis in cervical carcinoma cells. Cancer Lett., in press.

15. Kim, T.I.; Jin, S.H.; Kim, W.H.; Kang, E.H.; Choi, K.Y.; Kim, H.J.; Shin, S.K.; Kang, J.K. (2001). Prolonged activation of mitogenactivated protein kinases during NSAID-induced apoptosis in HT-29 colon cancer cells. Int. J. Colorectal Dis., 16(3): 167-173.

16. Kim, K.S.; Baek, S.J.; Flake, G.P.; Loftin, C.D.; Calvo, B.F.; Eling, T.E. (2002). Expression and regulation of non-steroidal antiinflammatory drug-activated gene $(N A G-1)$ in human and mouse tissue. Gastroenterology, 122(5): 1388-1398.

17. Kim, J.S.; Baek, S.J.; Sali, T.; Eling, T.E. (2005). The conventional non-steroidal anti-inflammatory drug sulindac sulfide arrests ovarian cancer cell growth via the expression of NAG-1/MIC-1/GDF-15. Mol. Cancer Ther., 4(3): 487- 493.

18. Kruh, G.D.; Gaughan, K.T.; Godwin, A.; Chan, A. (1995). Expression pattern of MRP in human tissues and adult solid tumor cell lines. $J$. Natl. Cancer Inst., 87(16): 1256-1258.

19. Lasko, D.; Cavenee, W.; Nordenskjold, M. (1991). Loss of constitutional heterozygosity in human cancer. Annu Rev. Genet., 25: 281-314.

20. Marks, F.; Müller-Decker, K.; Fürstenberger, G. (2000). A causal relationship between unscheduled eicosanoid signaling and tumor development: cancer chemoprevention by inhibitors of arachidonic acid metabolism. Toxicology, 153(1-3): 11-26.

21. Matsuhashi, N.; Nakajima, A.; Fukushima, F.; Yazaki, Y.; Oka, T. (1997). Effects of sulindac on sporadic colorectal adenomatous polyps. Gut., 40(3): 344-349.

22. Pasricha, P.J.; Bedi, A.; O'Connor K.; Rashid, A.; Akhtar, A.J.; Zahurak, M.L.; Piantadosi, S.; Hamilton, S.R.; Giardiello, F.M. (1995). The effects of sulindac on colorectal proliferation and apoptosis in familial adenomatous polyposis. Gastroenterology, 109(3): 994-998.

23. Qiao, L.; Shiff, S.J.; Rigas, B. (1997). Sulindac sulfide induces several subpopulations of colon cancer cells, defined by PCNA/Ki-67 and DNA strand breaks. Biochim. Biophys. Acta, 1359: 222-232.

24. Robertson, F.M.; Parrett, M.L.; Joarder, F.S.; Ross, M.; Abou-Issa, H.M.; Akhafie, G.; Harris, R.E. (1998). Ibuprofen-induced inhibition of cyclooxygenase isoform gene expression and regression of rat mammary carcinomas. Cancer Lett., 122(1-2): 165-175.

25. Rolland, P.H.; Martin P.M.; Jacquemier J.; Rolland, A.M.; Toga, M. (1980). Prostaglandin in human breast cancer: evidence suggesting that an elevated prostaglandin production is a marker of high metastatic potential for neoplastic cells. J. Natl. Cancer Inst., 64(5): 1061-1070.

26. Schrey, M.P.; Patel, K.V. (1995). Prostaglandin E2 production and metabolism in human breast cancer cells and breast fibroblasts. Regulation by inflammatory mediators. Br. J. Cancer, 72(6): 14121419.

27. Wu, Y.L.; Sun, B.; Zhang, X.J.; Wang, S.N.; He, H.Y.; Qiao, M.M.; Zhong, J.; Xu, J.Y. (2001). Growth inhibition and apoptosis induction of sulindac on human gastric cancer cells. World J. Gastroenterol, 7(6): 796-800. 